\title{
PENERAPAN METODE PEMBELAJARAN KOOPERATIF TIPE STUDENT TEAMS ACHIEVEMENT DIVISIONS (STAD) UNTUK MENINGKATKAN HASIL BELAJAR MAHASISWA PADA MATA KULIAH PERENCANAAN PEMBELAJARAN EKONOMI
}

\author{
Sumarni $^{1}$, Nora Susanti ${ }^{2}$ \\ Dosen Program Studi Pendidikan Ekonomi STKIP- PGRI Sumbar \\ Jl. Gunung Pangilun No.1, Padang Sumatera Barat \\ Email : bundafyra@yahoo.co.id
Submitted: 2015.12.30 Reviewed: 2016.06.22 Accepted: 2016.06.24
http://dx.doi.org/10.22202/economica.2015.v4.i1.351

\begin{abstract}
This Research is the efforts to improve student learning outcomes through STAD cooperative learning method and can improve learning outcomes of students in the subject of economics at STKIP Lesson Planning PGRI SUMBAR. This type of research is a classroom action research (PTK). The researchers goal of lifting the title this study with hope in the process of learning in Higher Education has been using a variety of methods, models and approaches in the learning process and the learners can be helped anyway. STAD cooperative learning method is just one of various methods, models and approaches in the learning process in the classroom. Selection of STAD cooperative learning method, because this method is very interesting to be applied in the process of learning, cooperative learning method STAD easily understood, internalized and practiced by the learners and does not require a long time in its application. The use of STAD cooperative learning method is expected to help faculty and students in learning activities in the classroom. Results of Action Research (PTK) is an increase in student learning outcomes in each cycle. In the first cycle measures the average value of 6.7 and followed students in the second cycle a significant increase in value of 9.2. From these results it can be concluded that through STAD cooperative learning methods to improve learning outcomes on student education courses STKIP PGRI SUMBAR economy.
\end{abstract}

Penelitian ini membahas tentang upaya peningkatan hasil belajar mahasiswa melalui metode pembelajaran kooperatif tipe STAD dan dapat meningkatkan hasil belajar mahasiswa pada mata kuliah Perencanaan Pembelajaran ekonomi di STKIP PGRI SUMBAR. Jenis penelitian ini adalah Penelitian Tindakan Kelas (PTK). Tujuan peneliti mengangkat judul penelitian ini dengan harapan dalam proses pembelajaran yang ada di Perguruan Tinggi sudah menggunakan berbagai metode, model, dan pendekatan dalam proses pembelajaran serta para peserta didik dapat terbantu pula. Pemilihan metode pembelajaran kooperatif tipe STAD, dikarenakan metode ini sangat menarik untuk diterapkan dalam proses pembelajaran, metode pembelajaran kooperatif tipe STAD mudah dipahami, dihayati dan dipraktekan oleh perserta didik serta tida membutuhkan waktu yang lama dalam penerapannya. Penggunaan metode pembelajaran kooperatif tipe STAD diharapkan dapat membantu dosen dan mahasiswa dalam kegiatan pembelajaran di dalam kelas. Hasil dari Penelitian Tindakan Kelas (PTK) ini terjadi peningkatan hasil belajar siswa pada setiap siklusnya. Pada tindakan siklus I rata-rata nilai mahasiswa 6,7 dan dilanjutkan pada siklus II terjadi peningkatan yang signifikan dengan nilai 9,2. Dari hasil penelitian ini dapat disimpulkan bahwa melalui metode pembelajaran kooperatif tipe STAD dapat meningkatkan hasil belajar pada mahasiswa program studi pendidikan ekonomi STKIP PGRI SUMBAR.

Keywords: entrepreneurship, knowledge work practices, the motivation industry achievers and interest of entrepreneurship 


\section{PENDAHULUAN}

Situasi belajar atau perkuliahan sangat mendukung berhasil atau tidaknya proses pembelajaran yang dirancang. Kemampuan dan kreatifitas dosen sebagai tenaga pengajar dituntut agar perkuliahan dapat berjalan dengan efektif dan menyenangkan. Dengan paradigma baru, pembelajaran dianggap gagal apabila mahasiswa hanya berhasil sebatas mencapai apa yang diajarkan atau hanya sebatas replikasi dosen. Sebaliknya, efektifitas pembelajaran akan tercapai apabila mahasiswa memiliki kompetensi dan mampu mengaplikasikan dan mentransformulasikannya dalam situasi atau tempat yang baru.

Menurut Nasution (1999:86) sekolahsekolah dan perguruan tinggi sering mendapatkan sorotan dan kecaman yang tajam dan dicap sebagai tempat yang membosankan. Kritikan ini merupakan akibat yang timbul dari strategi belajar mengajar yang monoton dan tidak kreatif. Sekolah termasuk perguruan tinggi terlalu banyak didominasi oleh metode ceramah, metode kuliah dan menjadikan dosen sebagai gudang ilmu yang akan ditransfer pada mahasiswa.

Metode ceramah merupakan cara yang cukup dominan digunakan saat ini. Dengan metode ini dosen berperan sebagai tokoh utama dalam perkuliahan dan menjelaskan materi secara gamblang kepada seluruh mahasiswa. Dari sudut pandang mahasiswa, terdapat berbagai kelemahan bila perkuliahan tetap didominasi oleh dosen. Kreatifitas mahasiswa kurang terasah karena terjebak pada rutinitas mencatat, mendengarkan dan mengerjakan latihan sesuai dengan instruksi yang diberikan. Mahasiswa kehilangan kesempatan untuk melihat ilmu sebagai sebuah realitas dan kaitan antara teori dengan aplikasinya di lapangan karena penjelasan yang diberikan sangat abstrak. Ketika mahasiswa dihadapkan pada kasus dengan kondisi riil di lapangan, mahasiswa tidak mampu menganalisis dan menerapkan konsep dan teori yang dimiliki untuk menyelesaikannya. Hal ini karena proses belajar hanya sampai pada taraf mengahafal. Selain itu, mahasiswa kurang terlatih dalam berbicara dan berkomunikasi. Padahal kemampuan ini cukup penting mengingat mahasiswa merupakan calon tenaga profesional di bidangnya. Mereka diharapkan mampu mempresentasikan kemampuan yang dimiliki sekaligus berinteraksi secara aktif dan positif dengan orang lain.

Metode ceramah yang terpusat pada dosen juga membawa mahasiswa masuk ke dalam kondisi belajar yang kurang menyenangkan. Proses pembelajaran memaksa mahasiswa untuk masuk kedalam situasi belajar yang kaku dan tegang sehingga mereka terisolasi dari kehidupan menyenangkan yang biasa mereka lalui sehari-hari. Akibatnya, perkuliahan menjadi membosankan, tidak menarik dan mahasiswa duduk di kelas karena tirani dan doktrinasi angka-angka. Padahal menurut Ellison dalam Dryden (2004:304) otak tidak bisa memperhatikan semua hal, pelajaran yang tidak menarik, membosankan atau tidak menggugah emosi, pastilah tidak akan diingat.

Mata kuliah Perencanaan Pembelajaran Ekonomi dengan bobot 3 (tiga) sks merupakan mata kuliah yang wajib diikut mahasiswa Pendidikan Ekonomi. Selain itu mata kuliah ini juga merupakan mata kuliah pra syarat untuk mengikuti Praktek Lapangan Kependidikan (PLK). Dalam melaksanakan perkuliahan penulis merasakan beberapa komponen penting dalam proses pengajaran belum berjalan secara optimal. Selama ini perkuliahan dilaksanakan dengan metode ceramah, presentasi individu, mengerjakan latihan termasuk resume dan tanya jawab. 
Namun ternyata masih terdapat banyak kelemahan.

Pertama, penulis menemukan pada beberapa kelas, terutama kelas dengan keahlian manajemen pemasaran, sebagian besar mahasiswa kurang aktif dalam perkuliahan. Keaktifan mereka hanya sebatas pada aktivitas menjawab pertanyaan apabila ditunjuk oleh dosen. Bila diminta untuk bertanya atau menanggapi pertanyaan, hampir tidak ada yang berinisiatif untuk melakukannya. Hal ini akhirnya mengakibatkan kegiatan pembelajaran terpusat pada dosen sehingga membentuk kebiasaan menyalin materi kuliah walaupun belum dipahami sepenuhya oleh mahasiswa.

Kedua, peneliti mengamati bahwa aktifitas mahasiswa ketika melaksanakan presentasi dirasa belum sempurna. Beberapa pertemuan pada mata kuliah Perencanaan Pembelajaran Ekonomi dilaksanakan dengan cara presentasi menjelaskan materi dengan menggunakan media, model pembelajaran ataupun berdasarkan RPP yang sudah mereka buat. Dalam melaksanakan presentasi mahasiswa dibagi dalam kelompok kecil yaitu 4 sampai 6 orang. Masing-masing kelompok menyelesaikan tugasnya di rumah. Pada saat pelaksanaan presentasi, kemampuan mahasiswa dalam menjelaskan materi sangat rendah dan hal ini berdampak kepada pelaksanaan presentasi yang tidak menarik. Dan kegiatan pembelajaran pun terpusat kembali kepada dosen karena disini dosen yang kembali melengkapi materi dan mengomentari penampilan mahasiswa.

Ketiga, rendahnya minat baca mahasiswa terhadap materi perkuliahan yang ada. Mahasiswa cenderung mau membaca ketika telah dihadapkan pada tugas. Selama ini mahasiswa diminta untuk menjawab soal-soal yang diberikan beberapa hari sebelum perkuliahan lewat blog. Soal-soal tersebut mewakili keseluruhan materi dari satu kali pertemuan. Pada saat perkuliahan mahasiswa akan dipanggil secara acak berdasarkan nomor absennya untuk menjawab satu pertanyaan. Namun ternyata masih tetap banyak yang tidak membaca materi dan ketika namanya terpanggil untuk menjawab salah satu soal, sebagian besar hanya membacakan buku saja. Ketika diminta untuk menjelaskan maksud dari buku tersebut, rata-rata mahasiswa tidak bisa menjelaskannya.

Beberapa faktor yang dikemukakan di atas menurut penulis merupakan penyebab terjadinya kesenjangan jalannya perkuliahan Perencanaan Pembelajaran Ekonomi. Hal ini dapat terlihat dari masih rendahnya perolehan nilai mahasiswa pada ujian semester JanuariJuni 2006.

Untuk mengantisipasi berbagai fenomena ini, perlu dikembangkan metode pembelajaran yang tepat dan dapat mengaktifkan mahasiswa, merangsang minat baca dan semangat belajar sekaligus menyenangkan. Metode pembelajaran akan menentukan seberapa jauh dan seberapa banyak pengalaman dan kemampuan yang akan dikuasai mahasiswa. Penguasaan dosen atas keanekaragaman metode pembelajaran merupakan salah satu garansi untuk mengelola materi kuliah dengan lebih menarik sehingga dapat lebih diserap mahasiswa.

Ada berbagai model pembelajaran yang dikembangkan saat ini. Salah satu model pembelajaran tersebut adalah Cooperative Learning Student Teams Achievement and Divisions (STAD). STAD telah digunakan dalam berbagai mata pelajaran yang ada, mulai dari matematika, bahasa, seni sampai dengan ilmu sosial dan ilmu pengetahuan ilmiah lain, dan telah digunakan mulai dari siswa kelas dua sampai perguruan tinggi (Slavin, 2008). Selanjutnya, Slavin (2008) mengungkapkan bahwa gagasan utama STAD adalah untuk memotivasi peserta didik supaya dapat saling mendukung dan membantu satu sama lain 
dalam menguasai kemampuan yang diajarkan oleh pendidik.

Dalam metode STAD ini proses pembelajaran dilaksanakan secara berkelompok, bekerja dalam tim untuk menguasai materi pelajaran untuk selanjutnya mahasiswa akan diberikan kuis secara sendirisendiri. Kemudian pencapaian yang diraih akan diberikan penghargaan oleh pendidik. Seluruh rangkaian kegiatan, termasuk presentasi yang disampaikan pendidik, praktik tim dan kuis biasanya memerlukan waktu 3-5 periode kelas.

Efektifitas implementasi cooperative learning dalam peningkatan kualitas pembelajaran juga telah diuji secara empiris oleh berbagai penelitian. Beberapa peneliti menyimpulkan bahwa pembelajaran kooperatif dapat meningkatkan motivasi dan hasil belajar siswa. Guru-guru memberikan tanggapan positif terhadap pembelajaran kooperatif yang mereka lakukan. Para guru juga mencatat bahwa siswa merespon dengan baik pengalaman kelompok kecil mereka dan itu membantu mereka untuk lebih mengatur dan menyusun pelajaran mereka (Gillies \& Boyle, 2010). Penelitian Wyk (2012) menemukan bahwa pembelajaran kooperatif tipe STAD pada pembelajaran ekonomi memberikan sikap belajar yang lebih positif, prestasi belajar yang lebih baik dan membuat mahasiswa termotivasi. Pembelajaran kooperatif lebih efektif dari pada metode ceramah. Hal ini ditunjukkan dari hasil belajar siswa yang diajar dengan metode pembelajaran kooperatif lebih tinggi dari pada hasil belajar siswa yang di ajar dengan menggunakan metode ceramah. Sementara itu, penelitian Dyson (2002) menemukan bahwa cooperative Learning yang dilaksanakan pada pelajaran pendidikan jasmani memberikan banyak manfaat. Hal ini terlihat dari: peran mahasiswa, kemampuan komunikasi, bekerja sama yang meningkat.
Penelitian-penelitian di atas telah mengungkap bahwa penerapan cooperative learning memberikan pengaruh yang positif dan dapat membantu pendidik dalam melaksanakan proses pembelajaran. Oleh karena itu, penulis yakin bahwa penerapan Metode Pembelajaran Cooperative learning tipe STAD dapat memberikan harapan yang cukup besar untuk meningkatkan hasil belajar mahasiswa dalam perkuliahan Perencanaan Pembelajaran Ekonomi. Namun penulis menyadari bahwa mengemukakan hasil survei saja belum memadai untuk membangun sebuah konsep pemecahan masalah yang lebih baik. Idealnya, penerapan Cooperative learning tipe STAD ini dapat dipertanggung jawabkan hasilnya melalui sebuah penelitian. Melihat kebermaknaan hasil penelitian yang dapat memperbaiki secara langsung proses pembalajaran di kelas, untuk mendalami masalah ini perlu dilakukan penelitian tindakan (action research) dengan judul "Penerapan Metode Pembelajaran Kooperatif Tipe Student Teams Achievement Divisions (STAD) untuk Meningkatkan Hasil Belajar Mahasiswa pada Mata Kuliah Perencanaan Pembelajaran Ekonomi”.

\section{METODE PENELITIAN}

Metode penelitian yang digunakan dapat diuraikan sebagai berikut:

\section{A. Jenis Penelitian}

Jenis penelitian ini adalah Penelitian Tindakan Kelas (PTK). Tujuan penelitian ini adalah untuk mendeskripsikan tentang penerapan metode pembelajaran kooperatif tipe Student Teams Achievement and Division (STAD) dalam meningkatkan hasil belajar mahasiswa pada mata kuliah Perencanaan Pembelajaran Ekonomi. Penelitian ini dilakukan di Program Studi Pendidikan Ekonomi STKIP PGRI Sumatera Barat tepatnya pada mahasiswa yang mengikuti Mata Kuliah Perencanaan Pembelajaran Ekonomi. Dalam pelaksanaannya, peneliti bekerjasama dengan salah seorang dosen untuk teman sejawat.

\section{B. Tempat, Waktu dan Subjek Penelitian Penelitian ini dilakukan di Program}


Studi Pendidikan Ekonomi STKIP PGRI Sumatera Barat Penelitian dilakukan pada bulan Februari 2015. Subjek penelitian ini adalah pada mahasiswa STKIP PGRI Sumatera Barat yang mengikuti Mata Kuliah Perencanaan Pembelajaran Ekonomi pada Sesi C. Dalam pelaksanaannya, peneliti bekerjasama dengan salah seorang dosen untuk teman sejawat.

\section{Sasaran Tindakan}

Sasaran dari penelitian ini yaitu perubahan yang diharapkan dari subjek yang diberikan tindakan, yaitu target yang diharapkan, yaitu terjadinya peningkatan aktivitas dan hasil belajar mahasiswa melalui metode pembelajaran koopratif tipe STAD.

\section{Rancangan Tindakan}

Rencana tindakan merupakan gambaran tentang langkah-langkah nyata yang akan dilakukan dalam tindkan. Kegiatan pelaksanaan penelitian akan dilalui melalui 4 tahapan yaitu; 1) Tahap Perencanaan, 2) Tahap pelaksanaan, 3) Tahap pengamatan, dan 4) Tahap refleksi. Data penelitian ini dikumpulkan dengan menggunakan lembaran observasi, wawancara dan hasil tes. Unsurunsur yang diamati dalam pelaksanaan mengacu pada apa yang tertera pada butir-butir lembar observasi.

\section{E. Instrument Penelitian}

Instrument atau alat yang digunakan dalam penelitian sebagai pengumpul data adalah:

\section{Lembar observasi}

a. Lembar observasi aktivitas siswa dalam belajar, digunakan untuk melihat aktivitas belajar siswa selama proses pembelajara.

b. Lembar observasi aktivitas dosen dalam mengajar, digunakan untuk melihat aktivitas dan kemampuan dosen dalam mengajar.
2. Tes

Tes yang diberikan berbentuk pertanyaan essay. Dosen memberikan penilaian terhadap pertanyaan-pertanyaan yang dijawab mahasiswa dengan jawaban yang betul. Penilaian ini bertujuan untuk mengetahui penguasaan mahasiswa atas materi yang disampaikan.

\section{F. Indikator Keberhasilan}

Penelitian tindakan kelas ini dikatakan berhasil apabila hasil belajar sebagian mahasiswa $(80 \%)$ telah memiliki nilai lebih dari 75 karena telah berada di atas kriteria ketuntasan minimum (KKM) yang telah ditentukan. Jadi apabila sudah $80 \%$ mahasiswa yang hasil belajarnya di atas 75 maka penelitian ini sudah bisa dihentikan dan dapat dikatakan berhasil.

\section{PEMBAHASAN}

\section{A. Hasil Penelitian Siklus 1}

\section{Perencanaan (Planning)}

Dalam pelaksanaan penelitian, terdapat rencana penelitian yang akan diaplikasikan dalam penelitian ini, yaitu:

1) Menentukan materi yang akan disampaikan, yaitu tentang Materi Pembelajaran.

2) Menyiapkan bahan ajar tentang Materi Pembelajaran.

3) Menyiapkan daftar hadir mahasiswa.

4) Menyiapkan media berupa power point yang dibutuhkan untuk mendukung proses pembelajaran yang menampilkan epitome dari materi yang akan diajarkan.

5) Menyiapkankan latihan yang akan dikerjakan mahasiswa setiap kali pertemuan.

6) Menyiapkan segala sesuatu yang dibutuhkan dalam kegiatan observasi, seperti lembaran observasi penelitian.

7) Menentukan observer selama pembelajaran berlangsung, yaitu teman sejawat yang akan membantu peneliti dalam melaksanakan penelitian. Sewaktu tindakan dilaksanakan, observer mengamati setiap aktivitas mahasiswia sesuai dengan format observasi dengan cara mengawasi mahasiswa sambil 
berkeliling di kelas kemudian duduk di depan atau di belakang kelas.

\section{Pelaksanaan (Action)}

Pertemuan Siklus I penelitian ini dilaksanakan pada hari Selasa tanggal 24 Februari 2015, perkuliahan Perencanaan Pengajaran Eknomi dimulai pada pukul 08.15 WIB sampai dengan pukul 09.45 WIB. Sebelum peneliti memulai pelajaran, peneliti dan observer telah siap berada di dalam kelas dengan lembar observasi.

Pada kegiatan awal, peneliti mengkondisikan kelas untuk mulai melaksanakan pembelajaran, mengabsen kehadiran mahasiswa dan menghitung jumlah mahasiswa yang hadir pada pertemuan pertama. Setelah itu peneliti melakukan apersepsi dan memotivasi mahasiswa serta menyampaikan tujuan pembelajaran kepada mahasiswa. Untuk pertemuan pertama, dibahas materi pelajaran.

Selanjutnya peneliti menginstruksikan kepada mahasiswa untuk membentuk kelompok belajar berdasarkan kelompok yang telah dibagi berdasarkan kemampuannya. Setiap kelompok yang telah terbentuk diinstruksikan untuk mengambil posisi kelompoknya. Agar sesuai dengan tujuan pembelajaran, peneliti memberikan bahan ajar dan membimbing kelompokkelompok belajar untuk mengerjakan materi pembelajaran melalui diskusi kelompok. Setelah waktu diskusi selesai. Setiap kelompok secara acak diminta mempersentasikan hasil diskusi kelompoknya di depan kelas. Setelah persentasi dosen bertanya jawab tentang halhal yang belum diketahui mahasiswa.

Setelah itu, peneliti melaksanakan evaluasi dalam bentuk kuis untuk mengetahui kemampuan belajar mahasiswa.
Selanjutnya kuis tersebut diperiksa oleh peneliti dan dikembalikan kepada mahasiswa sehingga mereka mengetahui hasil dari kemampuannya dan dapat memperbaiki letak kesalahannya. Peneliti menjelaskan bahwa bagi mahasiswa dan kelompok mahasiswa yang memperoleh nilai hasil belajar yang sempurna diberi penghargaan pada akhir pertemuan untuk memotivasi mereka.

Pada jam terakhir, secara bersama-sama peneliti dan mahasiswa bertanya jawab meluruskan kesalahapahaman, memberikan penguatan dan menyimpulkan materi pada hari tersebut. Selanjutnya mahasiswa diminta mencatat sendiri materi yang telah dipelajari sehingga mereka dapat menemukan initisari dari materi yang dipelajari dan kiat-kiat dalam menjawab soal. Peneliti juga menyiapkan tugas rumah mahasiswa, agar mereka membaca materi selanjutnya.

Pada kegiatan penutup peneliti menyampaikan kesimpulan dan memberikan tugas rumah kepada mahasiswa agar membaca materi untuk pertemuan berikutnya dengan membuat resume/ringkasan. Setelah pelajaran selesai, hasil lembaran observasi yang ada pada observer didiskusikan untuk membicarakan permasalahan-permasalahan yang berkaitan dengan jalannya proses pembelajaran.

\section{Pengamatan (Observation)}

\section{a. Aktivitas}

Berdasarkan pelaksanaan penelitian pada siklus I, dapat dilihat perkembangan aktivitas mahasiswa selama mengikuti proses pembelajaran pada siklus I. Namun, dalam peningkatan aktivitas mahasiswa ini tidak luput dari aktivitas dosen selama proses pembelajaran dapat dilihat pada Tabel 4 berikut ini: 
Tabel 1. Data Hasil Pengamatan Aktivitas Dosen pada Mata Kuliah Perencanaan Pengajaran Ekonomi untuk Siklus I

\begin{tabular}{|c|c|c|c|}
\hline \multirow{2}{*}{ No } & \multirow{2}{*}{ Kegiatan Dosen } & \multicolumn{2}{|c|}{ Siklus I } \\
\hline & & Nilai & Kategori \\
\hline 1 & Apersepsi & 3 & Baik \\
\hline 2 & Penjelasan Materi & 3 & Baik \\
\hline 3 & $\begin{array}{l}\text { Penggunaan Metode } \\
\text { Pembelajaran }\end{array}$ & 3 & Baik \\
\hline 4 & Penguasaan Kelas & 2 & Cukup \\
\hline 5 & Penggunaan Media & 3 & Baik \\
\hline 6 & Suara & 4 & $\begin{array}{l}\text { Sangat } \\
\text { Baik }\end{array}$ \\
\hline 7 & $\begin{array}{l}\text { Pemberian } \\
\text { Pertanyaan }\end{array}$ & 2 & Cukup \\
\hline 8 & $\begin{array}{l}\text { Pemberian } \\
\text { Penguatan }\end{array}$ & 1 & Kurang \\
\hline 9 & $\begin{array}{l}\text { Kemampuan } \\
\text { Mengevaluasi }\end{array}$ & 1 & Kurang \\
\hline 10 & $\begin{array}{c}\text { Menyimpulkan } \\
\text { Materi Pembelajaran }\end{array}$ & 3 & Baik \\
\hline & Jumlah & 25 & \\
\hline & $\begin{array}{c}\text { Rata-rata } \\
\% \text { Rata-rata nilai }\end{array}$ & $\begin{array}{c}2,5 \\
62,5 \%\end{array}$ & Tinggi \\
\hline
\end{tabular}

Berdasarkan Tabel 4 di atas, dapat diketahui bahwa tugas peneliti pada penggunaan metode pembelajaran kooperatif tipe Student Teams Achievement and Division (STAD) selama pembelajaran adalah tinggi, karena sudah hampir sesuai dengan langkahlangkah dalam metode STAD yang ada dalam teori. Namun, dalam hal ini aktivitas dosen akan ditingkatkan lagi pada siklus II agar tugas dosen dalam penggunaan metode pembelajaran kooperatif tipe Student Teams Achievement and Divisions (STAD) menjadi sangat baik.

Berdasarkan jumlah aktivitas yang dilakukan mahasiswa, maka dapat dibuat tabel yang berisi tentang masing-masing indikator aktivitas pada siklus I yang disajikan pada Tabel 6 berikut ini.

Gambaran aktivitas belajar mahasiswa STKIP PGRI SUMBAR selama proses pembelajaran berlangsung dengan menggunakan metode pembelajaran kooperatif tipe Studentt Teams Achievement and Division (STAD) pada siklus I yang disajikan pada Tabel 12 dapat diketahui bahwa secara umum aktivitas positif belajar mahasiswa mempunyai rata-rata sebesar 58\% kategori cukup. Namun, aktivitas positif mahasiswa masih ada yang berada dalam kategori cukup sehingga perlu peningkatan pada pertemuan selanjutnya dalam siklus II.

\section{b. Hasil Belajar}

Berdasarkan Hasil pengolahan data dapat diketahui nilai terendah yang diperoleh mahasiswa adalah 50 dan nilai tertinggi 80, mahasiswa yang tidak tuntas pada siklus I sebanyak 11 orang atau $55 \%$ dan secara klasikal ketuntasan siswa adalah $45 \%$ dengan rata-rata kelas 66. Hasil yang diperoleh pada siklus I belum sesuai dengan apa yang peneliti harapkan tercapai dari penelitian tindakan kelas (PTK) ini, maka penelitian dilanjutkan ke siklus II. 
Tabel 6. Data Hasil Pengamatan Aktivitas Mahasiswa pada Mata Kuliah Perencanaan Pengajaran Ekonomi Pada Siklus I

\begin{tabular}{lccc}
\hline \multirow{2}{*}{ Aktivitas Mahasiswa } & \multicolumn{2}{c}{ SIKLUS I } & \\
\cline { 2 - 3 } & \multicolumn{2}{c}{$\mathrm{N}=20$} & Kateg \\
ori \\
& $\begin{array}{c}\text { Jumlah } \\
\text { Bobot }\end{array}$ & $\%$ & \\
\hline $\begin{array}{l}\text { Membuat } \\
\text { resume/ringkasan materi } \\
\text { pelajaran }\end{array}$ & 54 & $68 \%$ & Tinggi \\
$\begin{array}{l}\text { Memperhatikan } \\
\text { penjelasan dosen }\end{array}$ & 49 & $61 \%$ & Tinggi \\
$\begin{array}{l}\text { Mengajukan pertanyaan } \\
\begin{array}{l}\text { Mengemukakan pendapat/ } \\
\text { tanggapan }\end{array}\end{array}$ & 35 & $44 \%$ & Cukup \\
$\begin{array}{l}\text { Menyerahkan lembar } \\
\text { latihan tepat waktu }\end{array}$ & 39 & $49 \%$ & Cukup \\
\hline \multicolumn{1}{c}{ Jumlah } & 55 & $69 \%$ & Tinggi \\
\hline \multicolumn{1}{c}{ Rata-rata } & 232 & $290 \%$ & \\
\hline \multicolumn{1}{c}{ Sumber: Pengolahan Data Primer, 2015 }
\end{tabular}

\section{Refleksi (Reflection)}

Berdasarkan analisis dari data yang diperoleh serta aktivitas yang diamati selama pembelajaran pada siklus I, peneliti menemukan beberapa kelemahan-kelemahan yang perlu diperbaiki dalam proses pembelajaran selanjutnya. Kelemahankelemahan tersebut di antaranya:

1) Mahasiswa yang terlibat aktif dalam pembelajaran belum sesuai dengan indikator yang diharapkan. Hal ini dapat dilihat dari rata-rata aktivitas positif mahasiswa dalam proses pembelajaran pada siklus I sebagai berikut:

2) Rata-rata nilai hasil tes pada siklus I belum mencapai target, di mana rata-rata nilai hanya 66 dan ketuntasan klasikalnya $45 \%$ sedangkan target rata-rata nilainya adalah sebesar $\geq 75$ dan ketuntasan klasikalnya $\geq 80 \%$.

Berdasarkan kenyataan tersebut, maka penelitian perlu dilanjutkan kepada siklus II. Pada siklus II, peneliti perlu melakukan perbaikan dalam pembelajaran, yaitu:

a) Perbaikan dalam pelaksanaan metode pembelajaran kooperatif tipe Student Teams Achievement and Division (STAD) agar pembelajaran berjalan lebih efektif dan efisien, yang diiringi dengan memberikan penghargaan dalam bentuk pujian, ancungan jempol serta hadiah (reward) bagi mahasiswa yang aktif, cermat, tanggap, dan cepat.

b) Keterampilan dosen dalam mengelola kelas masih perlu ditingkatkan. Dalam rangka meningkatkan aktivitas mahasiswa dalam belajar pada siklus berikutnya, dosen perlu memperhatikan komponenkomponen keterampilan pengelolaan kelas keterampilan yang berhubungan dengan penciptaan dan pemeliharaan kondisi belajar yang optimal (bersifat preventif) serta keterampilan yang berhubungan dengan pengembangan kondisi belajar yang optimal.

c) Keterampilan dosen memotivasi mahasiswa dalam pembelajaran masih perlu ditingkatkan. Berusaha memotivasi mahasiswa agar mereka membuat resume/ringkasan materi pelajaran setiap pertemuan, memperhatikan penjelasan dosen, mengajukan pertanyaan, mengemukakan pendapat/ tanggapan dan mengerjakan latihan serta menyerahkannya tepat waktu. Pada awal pembelajaran pada siklus berikutnya, dosen dapat memberikan motivasi dan menarik perhatian mahasiswa untuk belajar. 
d) Penggunaan media dalam pengajaran yang lebih menarik perhatian mahasiswa perlu ditingkatkan.

e) Dalam menyampaikan dan mengulas materi pelajaran dosen jangan terlalu cepat mengingat kemampuan masingmasing mahasiswa berbeda-beda.

f) Meningkatkan keterampilan dosen dalam pemberian penguatan dan kemampuan melakukan evaluasi.

g) Menegaskan waktu yang telah ditetapkan kepada mahasiswa untuk melakukan aktivitas seperti ketika mahasiswa diberi waktu membaca bahan ajar, mengerjakan latihan, karena pada suatu pengajaran langsung merencanakan dan mengelola waktu merupakan kegiatan yang sangat penting, serta memberikan instruksi dengan lebih jelas sehingga mereka tidak bingung dalam memahami dan melakukannya.

h) Bagi mahasiswa yang mencontek saat tes dilaksanakan akan diberikan teguran dan dosen memberi peringatan bahwa kertas lembaran jawaban mereka tidak akan diperiksa.

\section{Siklus 2}

\section{Perencanaan (planning)}

a) Menyiapkan perangkat pembelajaran sekaligus bahan ajar yang sudah disiapkan pada pertemuan sebelumnya yang merupakan lanjutan dari pertemuan sebelumnya, yaitu tentang Materi Pembelajaran.

b) Menyiapkan daftar hadir mahasiswa.

c) Menyiapkan media yang dibutuhkan untuk mendukung proses pembelajaran yang menampilkan epitome dari materi yang akan diajarkan.

d) Menyiapkankan latihan yang akan dikerjakan mahasiswa setiap kali pertemuan.

e) Menyiapkan tes soal objektif yang akan diberikan diakhir jam pelajaran.

f) Menyiapkan segala sesuatu yang dibutuhkan dalam kegiatan observasi, seperti lembaran observasi penelitian.

\section{Pelaksanaan (acting)}

Pelaksanaan pembelajaran pada siklus II ini sudah menunjukkan proses belajar mahasiswa sudah tampak lebih serius mengikuti pelajaran dibandingkan dengan pertemuan pertama. Hal ini disebabkan mereka sudah mulai paham terhadap materi dan proses pembelajaran.

Pada pertemuan kedua ini dosen memulainya dengan pengambilan absen dan mempersiapkan mahasiswa memulai pelajaran. Setelah itu, dosen menanyakan mengenai pelajaran pertemuan sebelumnya, dan kemudian membahas tugas yang telah diperintahkan kepada mahasiswa. Selanjutnya, dosen masuk kepada materi berikutnya yaitu lanjutan tentang Topik Materi Pembelajaran. Hal yang sama juga dilakukan, mahasiswa diminta untuk kembali berkelompok untuk mendiskusikan materi pelajaran dengan menggunakan metode STAD. Kemudian dosen memperhatikan sambil sesekali memberikan pertanyaan lemparan kepada siapapun yang kurang berkonsentrasi dalam diskusi kelompoknya. Pada waktu diskusi selesai, kembali dipanggil kelompok secara acak untuk menampilkan hasil diskusinya. Selanjutnya dosen bersama mahasiswa mengulas secara bersama dengan mengaitkan terhadap kehidupannya seharihari. Mahasiswa yang hadir pada saat itu antusias menyampaikan pendapatnya. Beberapa $\mathrm{mah}$ a siswa lain ikut menambahkan. Sedangkan beberapa diantaranya masih kesulitan. Untuk itu, saat jawaban kurang tepat dosen menambahkannya.

Pada kesempatan ini, dosen kembali melemparkan pertanyaan tersebut ke forum. Mahasiswa menampakkan keinginan untuk menjawab sambil mengacungkan tangan mereka. Setelah itu, dosen melaksanakan evaluasi dalam bentuk kuis baik secara individu untuk mengetahui kemampuan belajar mahasiswa. Selanjutnya kuis tersebut diperiksa oleh dosen dan dikembalikan kepada mahasiswa sehingga mereka mengetahui hasil dari kemampuannya dan dapat memperbaiki letak kesalahannya. Dosen menjelaskan bahwa bagi mahasiswa dan kelompok yang memperoleh nilai hasil belajar yang 
sempurna diberi penghargaan pada akhir pertemuan untuk memotivasi mereka.

Pada jam terakhir, secara bersama-sama disimpulkan apa yang telah dipelajari dengan menggunakan metode pembelajaran kooperatif tipe STAD ini, kemudian mahasiswa diberi tugas agar apa yang telah dipahami bisa diulang kembali di rumah.

\section{Pengamatan (observing)}

\section{a. Aktivitas}

Berdasarkan pelaksanaan penelitian pada siklus II, dapat dilihat perkembangan aktivitas mahasiswa selama mengikuti proses pembelajaran. Peningkatan aktivitas pada siklus II ini dapat dilihat dengan membandingkan aktivitas pada pertemuan pertama dan aktivitas pada pertemuan kedua. Namun, dalam peningkatan aktivitas ini tidak luput dari aktivitas dosen selama proses pembelajaran dapat dilihat pada Tabel 8 berikut ini:

Tabel 8. Data Hasil Pengamatan Aktivitas Dosen Mata Kuliah

Perencanaan Pengajaran Ekonomi

\begin{tabular}{|c|c|c|c|}
\hline \multirow{2}{*}{ No } & \multirow{2}{*}{ Kegiatan Dosen } & \multicolumn{2}{|c|}{ Siklus II } \\
\hline & & Nilai & Kategori \\
\hline 1 & Apersepsi & 4 & $\begin{array}{l}\text { Sangat } \\
\text { Baik }\end{array}$ \\
\hline 2 & Penjelasan Materi & 4 & $\begin{array}{l}\text { Sangat } \\
\text { Baik }\end{array}$ \\
\hline 3 & $\begin{array}{l}\text { Penggunaan Metode } \\
\text { Pembelajaran }\end{array}$ & 4 & $\begin{array}{l}\text { Sangat } \\
\text { Baik }\end{array}$ \\
\hline 4 & Penguasaan Kelas & 3 & Baik \\
\hline 5 & Penggunaan Media & 4 & $\begin{array}{l}\text { Sangat } \\
\text { Baik }\end{array}$ \\
\hline 6 & Suara & 4 & $\begin{array}{l}\text { Sangat } \\
\text { Baik }\end{array}$ \\
\hline 7 & Pemberian Pertanyaan & 3 & Baik \\
\hline 8 & Pemberian Penguatan & 4 & $\begin{array}{l}\text { Sangat } \\
\text { Baik }\end{array}$ \\
\hline 9 & $\begin{array}{l}\text { Kemampuan } \\
\text { Mengevaluasi }\end{array}$ & 3 & Baik \\
\hline 10 & $\begin{array}{l}\text { Menyimpulkan Materi } \\
\text { Pembelajaran }\end{array}$ & 4 & $\begin{array}{l}\text { Sangat } \\
\text { Baik }\end{array}$ \\
\hline & Jumlah & 37 & \\
\hline & Rata-rata & 3,7 & \\
\hline & $\%$ Rata-rata nilai & $92,5 \%$ & $\begin{array}{l}\text { Sangat } \\
\text { Tinggi }\end{array}$ \\
\hline
\end{tabular}

Sumber: Pengolahan Data Primer, 2015

Berdasarkan Tabel 8 tugas dosen pada pelaksanaan metode pembelajaran kooperatif tipe Student Teams Achievement and Divisions (STAD) pada Siklus II adalah sangat baik karena sudah sesuai dengan langkah-langkah STAD yang ada dalam teori. Dengan demikian, pembelajaran kooperatif tipe Student Teams Achievement and Divisions (STAD) ini dapat menjadikan dosen lebih kreatif, inovatif dalam mengelola dan mengorganisasi pembelajarannya, sehingga sebelum mengajar memang telah mempersiapkan segala 
sesuatunya dengan sebaik mungkin sehingga dalam mengajar tidak asal-asalan dan juga dapat meningkatkan keprofesionalan dalam mengajar.

Berdasarkan jumlah aktivitas yang dilakukan mahasiswa, maka dapat dibuat tabel yang berisi tentang masing-masing indikator aktivitas pada siklus II. Tabel 10 berikut menggambarkan ketercapaian masing-masing indikator aktivitas positif mahasiswa.

Tabel 10. Data Hasil Pengamatan Aktivitas Mahasiswa pada Siklus II

\begin{tabular}{|c|c|c|c|}
\hline \multirow{2}{*}{ Aktivitas Mahasiswa } & \multicolumn{2}{|c|}{$\begin{array}{c}\text { SIKLUS II } \\
\mathrm{N}=20\end{array}$} & \multirow{2}{*}{ Kategori } \\
\hline & $\begin{array}{c}\text { Jumlah } \\
\text { Bobot }\end{array}$ & $\%$ & \\
\hline $\begin{array}{l}\text { Membuat } \\
\text { resume/ringkasan materi } \\
\text { pelajaran }\end{array}$ & 71 & $89 \%$ & $\begin{array}{l}\text { Sangat } \\
\text { Tinggi }\end{array}$ \\
\hline $\begin{array}{l}\text { Memperhatikan } \\
\text { penjelasan dosen }\end{array}$ & 69 & $86 \%$ & $\begin{array}{l}\text { Sangat } \\
\text { Tinggi }\end{array}$ \\
\hline Mengajukan pertanyaan & 68 & $85 \%$ & $\begin{array}{l}\text { Sangat } \\
\text { Tinggi }\end{array}$ \\
\hline $\begin{array}{l}\text { Mengemukakan pendapat/ } \\
\text { tanggapan } \\
\text { Menyerahkan lembar }\end{array}$ & 71 & $89 \%$ & $\begin{array}{l}\text { Sangat } \\
\text { Tinggi } \\
\text { Sangat }\end{array}$ \\
\hline latihan tepat waktu & 72 & $90 \%$ & Tinggi \\
\hline Jumlah & 351 & $\begin{array}{c}439 \\
\%\end{array}$ & \\
\hline Rata-rata & 70,2 & $88 \%$ & $\begin{array}{l}\text { Sangat } \\
\text { Tinggi }\end{array}$ \\
\hline
\end{tabular}

Aktivitas belajar mahasiswa STKIP PGRI SUMBAR selama proses pembelajaran dengan menggunakan metode pembelajaran kooperatif tipe Studentt Teams Achievement and Division (STAD) pada siklus II yang disajikan pada Tabel 12 dapat diketahui bahwa secara umum aktivitas positif belajar mahasiswa mempunyai rata-rata sebesar $88 \%$ kategori sangat tinggi. Hal ini berarti tidak perlu dilanjutkan kepada siklus berikutnya karena sudah mencapai target yang ditetapkan.

\section{b. Hasil Belajar}

Berdasarkan hasil pengolahan data pada siklus II, dapat kita ketahui bahwa nilai terendah adalah 70 dan nilai tertinggi adalah 85 , dimana rata-rata kelas 78,5 dan persentase ketuntasan $85 \%$. Nilai rata-rata kelas dan persentase ketuntasan sudah mencapai target yang ditetapkan sehingga mahasiswa telah mencapai nilai di atas Kriteria Ketuntasan Minimal (KKM) yaitu 75.

\section{c. Refleksi (reflecting)}

Secara keseluruhan, baik aktivitas positif dan hasil belajar mahasiswa sudah mencapai hasil yang diharapkan. Hal ini dapat dilihat dari aktivitas positif mahasiswa dalam proses pembelajaran yang sudah berada pada kategori sangat tinggi. Namun demikian masih perlu juga terus ditingkatkan, terutama pada aktivitas positif mahasiswa yang bagian indikator mengajukan pertanyaan dan mengemukakan pendapat/tanggapan. 
Untuk hasil belajar, rata-rata hasil belajar mahasiswa sudah berada di atas standar Kriteria Ketuntasan Minimum (KKM) yang telah ditentukan yaitu 75. Tetapi pada siklus II ini masih terdapat 3 orang atau sebesar $15 \%$ yang tidak tuntas. Dari hasil pengamatan, mahasiswa yang tidak tuntas disebabkan aktivitasnya dalam belajar juga masih kurang. Hal ini mungkin terjadi karena pelaksanaan tindakan belum dilaksanakan secara optimal atau karena faktor lain seperti faktor internal yaitu faktor-faktor yang berasal dari dalam diri mereka.

Berdasarkan hal tersebut, jadi dapat dirumuskan bahwa persentase aktivitas positif mahasiswa selama proses pembelajaran mata kuliah Perencanaan Pengajaran Ekonomi pada siklus II terlihat bahwa masing-masing indikator aktivitas positif mahasiswa sudah mencapai target yaitu $\$ 81 \%$ dengan rata-rata aktivitas positif siswa sebesar 89,71\% Sedangkan hasil belajar mahasiswa pada siklus II dengan rata-rata kelas 65,65 dan ketuntasan klasikal 54,84\% mengalami peningkatan pada siklus II menjadi 78,5 untuk rata-rata kelas dan $88 \%$ untuk persentase ketuntasan klasikal. Hal ini sesuai dengan indikator keberhasilan yang diharapkan, yaitu persentase hasil belajar minimal $\mathbf{2 8 0 \%}$. Keberhasilan pada siklus II dapat dilihat dari adanya ketertarikan mahasiswa dalam mengikuti pembelajaran, berani untuk bertanya apa yang kurang dipahami, berani mengemukakan pendapat, memberikan tanggapan dan lain-lain. Jadi siklus II dinyatakan berhasil dan tidak perlu dilanjutkan kepada siklus berikutnya.

\section{B. Pembahasan}

Hasil penelitian pada siklus I hingga siklus II ditemukan bahwa dengan menggunakan Metode pembelajaran kooperatif tipe Student Teams Achievement and Divisions (STAD) pada mata kulian Perencanaan Pengajaran Ekonomi yang diterapkan pada Mahasiswa STKIP PGRI Sumbar Sesi C tahun 2015 menyebabkan aktivitas positif mahasiswa yang relevan dengan proses pembelajaran meningkat. Aktivitas positif mahasiswa dalam proses pembelajaran pada penelitian ini adalah membuat resume/ringkasan materi pelajaran, memperhatikan penjelasan guru, mengajukan pertanyaan, mengemukakan pendapat/tanggapan dan menyerahkan lembar latihan tepat waktu.

Pada siklus I rata-rata aktivitas positif mahasiswa sebesar 58\% meningkat pada siklus II menjadi $88 \%$. Hal ini sudah sesuai dengan indikator keberhasilan yang diharapkan yaitu persentase aktivitas positif mahasiswa yang relevan dengan pembelajaran adalah $\geq 81 \%$. Begitu juga dengan hasil belajar yang diperoleh mahasiswa pada siklus I dengan rata-rata kelas 66 dan ketuntasan klasikal 45\% mengalami peningkatan pada siklus II menjadi 78,5 untuk rata-rata kelas dan $85 \%$ untuk persentase ketuntasan klasikal.

Peserta didik dapat dikatakan berhasil apabila terjadi perubahan tingkah laku dalam dirinya baik berbentuk pengetahuan dan keterampilan maupun dalam bentuk sikap positif . Menurut Slameto (2003: 36), dalam proses mengajar belajar, pendidik perlu untuk menimbulkan aktivitas peserta didik dalam berpikir maupun bertindak. Dengan aktivitas peserta didik sendiri, pelajaran menjadi berkesan dan dipikirkan, diolah kemudian dikeluarkan lagi dalam bentuk yang berbeda; peserta didik akan bertanya, mengajukan pendapat, menimbulkan diskusi dengan pendidik. Dalam bertindak, peserta didik dapat menjalankan perintah, melaksanakan tugas, memmbuat grafik, diagram, intisari dari pelajaran yang disajikan. Bila peserta didik menjadi partisipan yang aktif, maka ia memiliki ilmu pengetahuan dan keterampilan dengan baik. Dengan demikian, peserta pembelajaran yang lebih aktif berpartisipasi di 
dalam proses pembelajaran akan lebih memiliki pengetahuan dan keterampilan yang baik dan mampu mengingat kembali materimateri yang diterimanya selama pembelajaran. Mereka akan memperoleh skor yang lebih baik ketika dievaluasi hasil belajarnya. Mereka akan memiliki hasil belajar yang lebih baik dibanding yang kurang aktif berpartisipasi dalam proses pembelajaran

Hasil penelitian ini juga menunjukkan terjadi peningkatan terhadap aktivitas dan hasil belajar mahasiswa setelah diterapkannya Metode pembelajaran kooperatif tipe Student Teams Achievement and Divisions (STAD). Pada Metode pembelajaran kooperatif tipe Student Teams Achievement and Divisions (STAD), setiap mahasiswa dapat terlibat aktif dalam pembelajaran.

Hasil penelitian ini sejalan dengan penelitian Wyk (2012) yang menemukan bahwa pembelajaran kooperatif tipe STAD pada pembelajaran ekonomi memberikan sikap belajar yang lebih positif, prestasi belajar yang lebih baik dan membuat mahasiswa termotivasi. Sardiman (2009: 145) menyatakan bahwa pendidik harus dapat merangsang dan memberikan dorongan serta reinforcement untuk mendinamisasikan potensi peserta didik, menumbuhkan swadaya (aktivitas) dan daya cipta (kreativitas) sehingga akan terjadi dinamika dalam proses belajar mengajar. Rangsangan dan dorongan tersebut telah pendidik berikan pada mahasiswa setelah memperoleh gambaran bahwa pada siklus I mahasiswa kurang termotivasi. Pemberian rangsangan inilah yang menjadi salah satu penyebab peningkatan aktivitas mahasiswa.

Aktivitas yang dilakukan oleh mahasiswa juga merupakan suatu bentuk keterlibatan atau pengalamannya secara langsung dengan pembelajaran. Hal ini seiring dengan yang dikemukakan oleh Edgar Dale (dalam Dimyati dan Mudjiono, 2006: 45) belajar paling baik adalah belajar melalui pengalaman langsung. Dalam belajar melalui pengalaman langsung peserta didik tidak sekedar mengamati secara langsung tetapi ia harus menghayati, terlibat langsung dalam perbuatan, dan bertanggung jawab terhadap hasilnya.

Secara keseluruhan aktivitas mahasiswa telah mencapai indikator keberhasilan yang diharapkan, namun masih banyak kendala yang pelu diperhatikan dalam pelaksanaan pembelajaran dengan Metode pembelajaran kooperatif tipe Student Teams Achievement and Divisions (STAD), yaitu perlunya ketegasan pendidik dalam menetapkan waktu untuk setiap langkah-langkah pembelajaran sehingga tujuan-tujuan yang diharapkan dalam setiap tahap dalam pembelajaran dapat diraih.

Dalam proses pembelajaran seorang pendidik dituntut untuk dapat memilih strategi serta model yang cocok dengan materi yang akan diberikan kepada peserta didik. Strategi dan model yang digunakan akan berpengaruh terhadap kualitas dan hasil dari proses belajar. Penggunaan Metode pembelajaran kooperatif tipe Student Teams Achievement and Divisions (STAD) mampu meningkatkan kemampuan mahasiswa untuk meningkatkan penguasaannya terhadap suatu materi pelajaran. Sebagaimana yang diungkapkan oleh Slavin (2008) bahwa gagasan utama STAD adalah untuk memotivasi peserta didik supaya dapat saling mendukung dan membantu satu sama lain dalam menguasai kemampuan yang diajarkan oleh pendidik. Begitu juga yang diungkapkan Uno (2009: 146) bahwa pengorganisasian pengajaran yang disusun sedemikian rupa sehingga mampu membangun struktur kognitif peserta didik terhadap pengetahuan baru yang akan dipelajari, akan memberikan hasil belajar yang baik. Karena Metode pembelajaran kooperatif tipe Student Teams Achievement and Divisions 
(STAD)ini berkaitan dengan proses ingatan, maka motivasi mahasiswa untuk mengikuti pembelajaran meningkat dan akan terjadi juga peningkatan terhadap aktivitas belajarnya karena motivasi merupakan tenaga pendorong untuk melakukan aktivitas dalam belajar. Kesesuaian urutan elaborasi dengan proses urutan pembentukan ingatan, tidak saja meningkatkan ingatan. Tetapi juga menjadikan belajar lebih efisien dan mendorong keaktifan mahasiswa dalam proses pembelajaran sehingga mampu meningkatkan hasil belajar yang diperolehnya. Metode pembelajaran kooperatif tipe Student Teams Achievement and Divisions (STAD) mensiasati dan merencanakan agar semua komponen pembentukan instruksional mengarah kepada tersampaikan isi pelajaran kepada peserta didik mengenai semua fakta, prinsip dan konsep yang mereka butuhkan. Dengan tercapainya tingkat penguasaan hasil pelajaran yang tinggi, maka akan menunjukkan sikap mental yang sehat pada mahasiswa yang bersangkutan.

\section{PENUTUP}

Berdasarkan hasil penelitian yang sudah dilakukan, maka dapat disimpulkan beberapa hal sebagai berikut:

1. Penggunaan Metode pembelajaran kooperatif tipe Student Teams Achievement and Divisions (STAD) pada Sesi C Mahasiswa STKIP PGRI Sumatera Barat dapat meningkatkan aktivitas positif mahasiswa atau aktivitas yang relevan dengan pembelajaran, dengan persentase $60 \%$ pada siklus I, dan meningkat menjadi $89 \%$ pada siklus II.

2. Penggunaan Metode pembelajaran kooperatif tipe Student Teams Achievement and Divisions (STAD) pada Sesi C Mahasiswa STKIP PGRI Sumatera Barat juga dapat meningkatkan hasil belajar mahasiswa. Hal ini terlihat pada siklus I, dimana nilai rata-rata 66 dengan persentase ketuntasan $45 \%$. Pada siklus II nilai rata- rata kelas meningkat menjadi 80 dengan persentase ketuntasan $85 \%$. Berdasarkan nilai yang diperoleh mahasiswa dapat disimpulkan bahwa Metode pembelajaran kooperatif tipe Student Teams Achievement and Divisions (STAD) berhasil digunakan pada penelitian tindakan kelas ini.

Berdasarkan proses penelitian dan hasil belajar yang diperoleh mahasiswa, maka diketahui bahwa model pembelajaran Student Team Achievemen and Divisions (STAD) ini terbukti dapat meningkatkan aktivitas dan hasil belajar mahasiswa pada mata kuliah perencanaan pengajaran ekonomi. Oleh karena ini peneliti dapat menyarankan kepada dosen lainnya untuk dapat menggunakan model pembelajaran ini sebagai salah satu alternatif untuk meningkatkan aktivitas dan hasil belajar mahasiswa.

\section{DAFTAR PUSTAKA}

10.22202/economica.2015.v4.i1.351

Arikunto, Suharsimi. 2007. Penelitian tindakan kelas. Jakarta: Bumi Aksara. 2002. Prosedur Penelitian Suatu Pendekatan Praktek. Jakarta: Rineka Cipta

Dryden Gordon. (2004). The Learning Revolution (Revolusi Cara Belajar). Edisi Indonesia. Bandung : Mizan Media Utama.

Dyson, Ben. (2002). The Implementation of Cooperative Learning in an Elementary Physical Education Program. Journal of Teaching in Physical Education, 2002, 22, 69-85.

Gillies, Robyn, Boyle, Michael. (2010). Teachers' Reflections on Cooperative Learning: Issues of Implementation. Teaching and Teacher Education: An International Journal of Research and Study. 26 (2010) p. 933 - 940.

Hamalik, Oemar. (2004). Perencanaan Pengajaran Berdasarkan Pendekatan Konsep. Jakarta : Bumi Aksara.Lie, Anita. 2002.Cooperative Learning. Jakarta: Grasindo.

Lie, Anita. 2002.Cooperative Learning. Jakarta: Grasindo. 
Miles, M. B dan A.M. Huberman. 2002. Analisis Data Kualitatif. Buku Sumber tentang Metode-metode Baru. Terjemahan Tjetjep Rohindi Rohidi. UI Press: Jakarta.

Nasution. (1999). Kurikulum dan Pengajaran. Bandung : Bumi Aksara.

Sagala, Syaiful. 2003. Konsep dan makna pembelajaran. Bandung: Alfabeta.

Sanjaya, Wina. 2010. Strategi pembelajaran berorientasi standar proses pendidikan. Jakarta: Kencana Prenada Media Group.

Silberman, Melvin L. 2006. Active Learning (edisi revisi). Bandung: Nusamedia.
Slameto. 2003. Belajar dan faktor-faktor yang mempengaruhinya. Jakarta: Rineka Cipta.

Slavin, R. E. 2008. Cooperative Learning: Theory, Research, and Practice. Boston: Asiman and Schuster Co.

Sudjana, Nana. 2001. Penilaian hasil belajar. Jakarta: Rineka Cipta.

Wardhani. 2007. Penelitian Tindakan Kelas. Jakarta: UT

Wyk, Micheal M Van. (2012). The Effects of the STAD-Cooperative Learning Method on Student Achievement, Attitude and Motivation inEconomics Education. Journal Social Science, 33(2): 261-270 (2012) 